\title{
DE
}

Karol Chylak (University of Social Sciences, Łódź)

\section{SOCIAL INSURANCE IN THE SECOND REPUBLIC OF POLAND. SOCIAL ADVANTAGE OR THE POLICY OF CAUTION}

Social insurance was conceived from a great thought of the social caution, from the thought of protection of an uncertain future. That thought of caution, during the time of development of social insurance, was implemented by the public entities on the one hand and by the civil activity on the other one. However, the process of creation of the social insurance system in Poland did not represent the policy of caution executed by the state. The only sign of caution could be seen with reference to the insurance associations as there the participants decided whether to enter the system or not whereas the state executed the policy of giving privileges to the certain social groups

Keywords: Second Polish Republic, Social insurance, Social policy, Social advantages

doi:10.1515/sho-2015-0003

\section{INTRODUCTION}

"Social insurance was conceived from a great thought of the social caution, from the thought of protection an uncertain future" - this was how in 1936 a well-known researcher of the social science, Konstanty Krzeczkowski, presented an origin of social insurance. He said, in addition, that "like every other great ideas of the mankind, it originated from utopia, peoples imagination chasing the best way of meeting of the needs of people". ${ }^{1}$ That thought of caution, during the time of development of social insurance, was implemented by the public entities on the one hand and by the civil activity on the other one. The thought was materialized

${ }^{1}$ Krzeczkowski Konstanty, Idee przewodnie ubezpieczeń społecznych [The guiding ideas of social security], Drukarnia Piotr Pyz i S-ka, Warszawa 1936, p. 9. 
in forms based on the principle of both, state and private insurance which operated in accordance with the rule of self reliance of the united participants.

The guilds, sodalities which had existed since the medieval times and had been built based on corporate principle, were not usually considered as insurance institutions. It was because of a lack of interdependence between the social benefits and contributions, which were usually collected only if there was a need. They were rather considered as the social welfare and donor institutions. ${ }^{2}$ In fact, the original idea of the private insurance was based on the principle of caution of the united participants. In addition, participation in such institution was not a privilege as its membership resulted from decision of the possible member, as well as from the organizational level of the given institution. Of course, such institutions were not universal. In such system one might have met both, insured and uninsured persons, however their status did not depend on any privileges given to one or the other group.

Over time, especially in Europe, the aforementioned form of insurance have been replaced by the mandatory state insurance. The state, which have been emerged over the centuries as a legal - public organization, have been given new or more precisely described rights and duties towards its citizens. Among all of the duties there was an obligation of taking care of its citizens in case of illness, accident, disability to earn money or other misfortune. The state became an organizer of the insurance system. Insurance stopped being facultative and became obligatory. The most important issue was the range, i.e. who was supposed to obey the obligation. Why was an employee of one company insured, whereas an employee of the other one was not? In this place we have started divagating on special rights and privileges. An attempt to analyze that issue is, in fact, a subject of this work.

2 Ibidem, p. 29; Daszyńska-Golińska Zofia, Ubezpieczenia społeczne [Social security], Międzynarodowa Sekcja Wydawnicza Słuchaczów Wolnej Wszechnicy Polskiej, Warszawa 1929, p. 7; Grabowski Edward, Ubezpieczenia społeczne w państwach wspótczesnych [Social security in contemporary states], Wende i S-ka, Warszawa 1923, p. 4-5. 


\section{BEGINNINGS OF THE SOCIAL INSURANCE IN POLAND}

In Poland, social insurance have been implemented by the partitioning countries, however in each of them the system has been built based on separate principles. Although many elements were similar, a considerable amount of local conditions as well as application of alternative solutions led to differences so considerable that the systems were separate. It considered organizational matters, as well as principles of financing and the scope and range of insurance. Financial and organizational separateness of the particular area of insurance dedicated to cover the particular risk was a commonly applied principle. In 1879, a well-known German economist, Lujo Brenato, selected six basis risks which should be insured: illness, misadventure, oldness, unemployment, children who were left orphans (up to 15 year old) and a funeral. ${ }^{3}$ The aforementioned situations were insured within the insurance, illness, disablement or pension system as well as unemployment system which was created as the final one.

Mandatory insurance, as such a form became inevitable because of the definition of the subject, have been introduced in Germany at first. ${ }^{4}$ It was during Otto von Bismarck governance, who - as a consequence - became a sort of symbol of it. In 1883 mandatory insurance against illnesses was introduced, whereas in 1884 they implemented insurance against misadventures and in 1889 against incapability to work (so called disablement insurance). In 1911, based on the law of in that regard, which had been created over several decades, a uniform text regarding insurance was published. In addition, it was supplemented with the system dedicated to white-collar employees of the private sector.

Insurance against sickness was obligatory for factory workers, railway men as well as workers of inland shipping and trade, craftsmen and workers of all factories which were equipped with devices with mechanical (steam, gas, water) drive. It was also mandatory for white-collar workers (for example referents and assistants in the legal offices, notary's offices, debt collectors' offices) employed in the management of the insurance institutions, post offices and telegraphs or, alternatively, in the army. Only

${ }^{3}$ Brentano Lujo, Die Arbeiterversicherung gemäss der heutigen Wirtschaftsordnung: Geschichtliche und ökonomische Studien, Duncker \& Humblot, Leipzig 1879, p. 22-31.

${ }^{4}$ Daszyńska-Golińska Zofia, Polityka społeczna [Social policy], Towarzystwo Bratniej Pomocy Studentów Wolnej Wszechnicy Polskiej, Warszawa 1933, p. 352. 
persons, whose daily or annual income exceeded the given, defined in the act, amount, were exempted from such obligation. ${ }^{5}$ In 1911 the obligation was imposed on the farm workers. It seems that the way the legislator listed the particular occupational groups, has given them a sort of privileged position, in comparison to the rest of the population and such statement wouldn't have been incorrect. Not only have the mandatory insured people had the rights to the benefits, but have also been granted a financial aid from an employer, who has been obliged to participate in the costs of maintenance of the whole system. The remaining part of the society has been given right to accede the insurance system (so called Eingeschriebenne Hülfskassen and Landesriechilche Hülfskassen) however the whole burden of financing the system has been taken by the insured. ${ }^{6}$ During that period of time (which has lasted over several decades), when insurance against sickness system has operated in Germany, the system has been extended over another occupational groups. Consequently, the privileged status has been limited. All in all, never has the prevalence of insurance against sickness been introduced in the Prussian annexation.

In Germany, since 1884, all employed persons have been granted the mandatory insurance against work-related accidents. In the consecutive years, the insurance obligation has been extended over another groups, so in 1911 the system became almost general in the whole country. Almost, as workers who had been earning over a particular - defined in the act -amount has never been obliged to accede. In that system the whole contribution / fine/ superannuation has been paid by the employer. Moreover, there has been a principle that a risk of an accident has been taken by an employer. ${ }^{7}$

Disablement insurance was added to the system in 1911. In fact, it was insurance against incapability to work due to the reason other than workrelated accident (Invaliditäts und Alters-Versicherung). First of all, it considered oldness and long-lasting illness. This insurance was mandatory for the certain group of employees and was optional for the rest. Similar to the insurance against sickness, for the particular group of employees list-

${ }^{5}$ Grabowski Edward, Ubezpieczenia społeczne... [Social security...], p. 16-17, 124-126; Kramsztyk Feliks, Prawo fabryczne obowiazujące i ubezpieczenie robotników w niektórych państwach europejskich [Applicable factory law and workers' insurance in some European states], Drukarnia S. Orgelbranda Synów, Warszawa 1896, p. 93.

${ }^{6}$ Grabowski Edward, Ubezpieczenia społeczne... [Social security...], p. 135.

${ }^{7}$ Ibidem, p. 56-59; Kramsztyk Feliks, Prawo fabryczne... [Applicable factory law...], p. 101. 
ed in the legislation, half of the superannuation was paid by the employer. Moreover, retirement pension of the person who belonged to the system, was supported with the benefit from the state budget whereas the remaining citizens had to take care of their future on their own. ${ }^{8}$ This kind of insurance was implemented in 1911 for white-collar employees of the private sector, however it was based on different organizational and financial principles. ${ }^{9}$

Mine workers were separate, truly privileged, occupational group. Not only had they a full range of insurance against sickness, work-related accident, incapability to work or death, but the insurance covered their families as well. In addition, insurance institutions in mining industry had long-lasting tradition, they had been operating since the medieval times, at first as the self-help institutions. In the middle of the nineteenth century, the institutions which have already existed, have been given a form of insurance institution (Knappschaftsverein). In the 1980s they were entered into the existing social insurance system. Moreover, entrepreneurs participated in the insurance premium. ${ }^{10}$

Contracted workers were somehow privileged in comparison to the other groups of employees. However, the employees of the state's administration were even more privileged as they all had a full coverage of insurance against the aforementioned risks and - moreover - it was guaranteed by the state's budget. ${ }^{11}$ Although the system of insurance of administrative employees can hardly be described as insurance system in its classic form, it covered the same range of risks. Therefore, in this particular case it certainly was a privileged position.

While analyzing German insurance introduced in Poland, it could be seen that they applied favouritism to the particular social groups. However, as it seems, it was not an assumption of the system, but resulted

${ }^{8}$ Grabowski Edward, Ubezpieczenia społeczne... [Social security...], p. 189-191; Kramsztyk Feliks, Prawo fabryczne... [Applicable factory law...], p. 111-112.

${ }^{9}$ Grabowski Edward, Ubezpieczenia społeczne... [Social security...], p. 234-236.

10 Piernikarczyk Józef, Pierwsza polska ustawa górnicza, czyli "Ordunek Górny". Historyczny dokument Górnego Ślaska z 1528 r. [The first Polish mining law, "Mining Order". Historical document of Upper Silesia from 1528], Nakładem Józefa Piernikarczyka, Tarnowskie Góry 1928, passim; Wanatowicz Maria, Ubezpieczenia brackie na Górnym Ślasku w latach 1922-1939 [Guild insurance in Upper Silesia in the years 1922-1939], Państwowe Wydawnictwo Naukowe, Warszawa-Kraków 1973, p. 17-20; Wanatowicz Maria, Pszczyńskie Bractwo Górnicze w okresie międzywojennym [Miners' Guild in Pszczyna in the interwar period], Studia i materiały z dziejów Śląska, no. 11/1971, p. 183-185.

${ }_{11}$ Grabowski Edward, Ubezpieczenia społeczne... [Social security...], p. 235-236. 
from dominating conservative perspective of the society, which was defined as a gathering of the social groups which differentiated in their status, their rights and duties, material as well as intellectual status. It seems as if the last two of the aforementioned aspects were the most crucial for the construction of the insurance system as in each of the insurance, there was a limit regarding a maximum salary, over which there was no insurance obligation with reference to the white-collar workers. Summarizing, social insurance in Germany, and in Poland as a part of its jurisdiction at the time, without any doubt granted both, rights and duties to the selected social groups and in such context it might be considered as a form of privilege. In addition, it is hard to resist the impression that the insurance might have been used by the authorities as an instrument to gain support or weaken someone's political position.

Almost simultaneously, social insurance was introduced in the Habsburg Monarchy, which resulted in their appearance in Galicia. The governors of Austria, as Galicia was a part of Austrian jurisdiction, used German solutions, however they used to modify them in order to adjust them to the local conditions and needs.

Insurance against work-related accidents were introduced as the first ones, on December 28, 1887, effectively it became valid since November 1889 , when insurance obligation was enacted. It covered employees of industrial factories, ironworks, mines, construction and the building industry, quarries as well as in enterprises using explosives at the manufacturing process and the agricultural and forestry enterprises which used motorized devices (precisely speaking, the workers using directly the aforementioned machines). ${ }^{12}$ In the consecutive years, occupational groups under insurance obligation were extended. In addition, an optional, voluntary insurance was introduced. ${ }^{13}$ Contributions, like in Germany, were debited an account of an employer.

Insurance against sickness was introduced as the second however the directive became effective a few months before the law regulating insurance against work-related insurance. A scope of insurance obligation was merely the same as the one regarding work-related accidents however there were a few additional exclusions. It was not obliged for communal,

12 Dziennik Ustaw Państwa dla Królestw i Krajów w Radzie Państwa Reprezentowanych [Journal of Laws of the State for Kingdoms and Countries Represented in the Council of State] (DzUPKKRPR) 1888, item 1.

13 DzUPKKRPR, 1908, item 162; item 168; Grabowski Edward, Ubezpieczenia społeczne... [Social security...], p. 73-78. 
district and the state clerks as well as temporary workers and white-collar employees who were employed in agricultural and forestry sector, for whom it was planned to organize a separate insurance system. Moreover, like in Germany, there was an option of a voluntary insurance. ${ }^{14}$

In 1906 in Austria a law regarding the pension insurance of white-collar employees was enacted. It was applied to all employees of the private sector whose annual income reached the particular level. This way, a part of society was given opportunity to have insurance in case of disability to work due to the reason other than work-related accident, whereas the rest of the society did not have such option. ${ }^{15}$ Disablement insurance did not exist in Austria.

Again, like in Germany, mine workers constituted an exception from the general rule. Since 1854 entrepreneurs in mine industry have been obliged to establish the so called fraternity funds (orig.: kasa bracka, Hilfkasse, Knapkasse). They started operating in Galicia and Cieszyn Silesia (orig.: Śląsk Cieszyński). ${ }^{16}$ They secured risks connected with sickness, work-related accidents or incapability to work. With time, due to the fact of introducing another social insurance, the fraternity funds were included in the system.

In principle, the situation in Austria did not differentiate from the one in Germany. Although organization and financing were different, in both systems it could be seen that there were privileges for the particular social and occupational groups, especially with reference to the mine workers, railway men, clerks of the civil service as well as the white-collar employees of the private sector. Also in this case it might be stated that the situation resulted from conservative point of view of the society. It was not intentional, however. It was not about giving privileges, but resulted rather from political and financial pragmatism.

While in both, Prussian and Austrian annexation social insurance systems were constructed, hardly anything happened in Russia in that regard. Actually, all risks regarding work-related accidents and sickness

14 DzUPKKRPR, 1888, item 33, 1889, item 39.

15 DzUPKKRPR, 1909, item 1; 1914, item 138; Sprawozdanie Towarzystwa Wzajemnych Ubezpieczeń Urzędników Prywatnych za rok 1907 i wstęp historyczny o czterdziestoletniej działalności Towarzystwa (1868-1908) [The Report of the Society of Mutual Insurance for Private Officials for 1907 and a historical introduction on 40 years of the Society's activity], Towarzystwo Wzajemnych Ubezpieczeń Urzędników Prywatnych, Lwów 1908, p. 11-12.

16 The National Archives in Krakow (Archiwum Narodowe w Krakowie), The Mining Starostship in Krakow (Starostwo Górnicze w Krakowie II), sign. 242, p. 41, Księga kas bratnich i bractw górniczych [The Book of Guild Banks and Mining Guilds]. 
were transferred to the employers, which resulted from The Napoleonic Code, industrial law as of 1866 and - later - from the directive as of 1903 which regulated compensations for work-related accidents. ${ }^{17}$ Therefore, any caution policy as well as intention to give any privileges regarding social insurance to the particular groups could hardly be seen. There was, however, an exception, which were employees of administration who had all risks related to sickness as well incapability to work secured by the state budget.

A privileged position could be mentioned only in case of mine and steel industry, which resulted from activity of the authorities of the Congress Poland. Since the 20s of the nineteenth century they have attempted to secure risks for the employees of the aforementioned industries. However, a ubiquitous insurance system has not been introduces. ${ }^{18}$ In Russia insurance institutions were established mainly based on private initiative undertaken in mechanised companies. Like in Austria or Germany, the fraternity funds were set-up, as well as funds by the guilds, by factories, different pension and provident funds based on the associationalism..$^{19}$ Insurance in railway industry was slightly different from the one mentioned above. It was based on the principle of reciprocal support. Sometimes the fund was donated by the entrepreneur. Although such activity was not a rule, it was not on an exceptional basis as well.

A process of introducing insurance institutions resulted - in principle - from a caution policy of their participants. Russian authorities were not enthusiastic towards the initiative as with reference to any activity which did not resulted from their own idea. They did not present an attitude of awareness which would aim at creation of social activity as well as

17 Wasiutyński Bohdan, Ubezpieczenia robotnicze w państwie rosyjskim [Workers' insurance in the Russian state], Ekonomista, no. 1/1913, p. 155-158; Kossuth Stefan, Prawo fabryczne z dnia 3/15 czerwca 1886 roku, jego znaczenie, zasady, treść i zastosowanie [Factory law of June 3/15, 1886, its importance, rules, content and application], Redakcya „Dziennika Łódzkiego", Łódź 1887, p. 77-78; Kodex Napoleona [Napoleonic Code], Drukarnia XX. Pijarów, Warszawa 1810, p. 361-362.

18 Gąsiorowska Natalia, Organizacja Kas Brackich górniczych w Królestwie Polskiem (18151830) [The organization of Guild Banks in the Kingdom of Poland (1815-1830)], Kwartalnik Historyczny 1928 , no. 2/1928, p. 297-301; Pindelski Tadeusz, Kasy emerytalne w przemyśle górniczo-hutniczym w b. Królestwie Kongresowem [Pension fund in the mining and steel industry in former Congress Poland], Przegląd Górniczo-Hutniczy, no. 20/1924, p. 1196-1197.

${ }^{19}$ Wóycicki Aleksander, Instytucje fabryczne i społeczne w przemyśle Królestwa Polskiego Factory and social institutions in industry in the Kingdom of Poland], Ekonomista, no. 4/1914, p. 50-58, 79; Grabowski Edward, Ubezpieczenia społeczne... [Social security...], p. 153-155; Wasiutyński Bohdan, Ubezpieczenia robotnicze... [Workers' insurance...], p. 158. 
at initiation of attitudes which would be able to foresee the potential risks and to knowingly mitigate them. Indeed, that way, the state authorities did not put contribution to create privileged groups by social insurance.

Since the beginning of the 20th century, works aiming at organization of the insurance system have been started. The authorities patterned themselves on the German and Austrian solutions in that regard. After several years of debates, in 1912, a law was enacted.$^{20}$ It was planned that the system would be run in phases. In Congress Poland it was supposed to be effective in 1915, however six months before the date the First World Was broke out, which ruined plans of the Russian authorities in that regard.

\section{REORGANIZATION AND THE PROCESS OF GIVING PRIVILEGES WITH REFERENCE TO THE SOCIAL INSURANCE TO THE CERTAIN SOCIAL AND OCCUPATIONAL GROUPS}

An outburst of the First World Was as well as regaining independence by Poland inevitably constituted an opening of the new chapter in the history of Poland and Poles. The situation of social insurance was very complicated. It was not possible to start everything all over, without consideration of the past. Insurance systems, which were inherited from the partitions still existed, or more, they had to existed as there were commitments towards the insured people. Without any doubt, though, the situation changed. First of all, the leading position was given in other hands, which was visible during the Congress Poland under the German occupation. In both, Provisional Council of State and afterwards in the Council of Ministers separate units were formed. Their task was to build the social insurance system. The members of the units were - in majority - from leftwing environments. ${ }^{21}$ Not only did they maintain their assets in the newly

20 Orłowski A. [Wróblewski Wacław], Ubezpieczenie społeczne w Dumie Państwowej [Social security in State Duma], Księgarnia G. Centnerszwera i Ski, Warszawa 1912, p. 2126; Dański B. [Komorowski Kazimierz], Ubezpieczenie robotników [Workers' insurance], Petersburg 1913, p. I-XI; Lewy Marceli, Nowa ustawa o ubezpieczeniu od wypadków przy pracy [New act on workplace accident insurance], Księgarnia Powszechna, Warszawa 1913, p. 3-4; Wasiutyński Bohdan, Ubezpieczenia robotnicze... [Workers' insurance...], p. 163-164.

21 Prace Departamentów i Biur Tymczasowej Rady Stanu Królestwa Polskiego wykonane lub przygotowane przez czas jej istnienia, t.j. od dnia 15 stycznia do 1 września 1917 r. [Works of 
formed systems of authorities of the independent Poland, but they managed to increase their inventory. ${ }^{22}$ In practice, it meant that the new concept of both, social insurance and the whole social policy would be implemented. A conservative view of the society was rejected for the benefit of perspective based on critics of the dividing society into estates. In addition, thinking of the society from class point of view was favoured.

Goals were very ambitious. It was planned that a new, ubiquitous social insurance system would be created. In May 1919 Tadeusz Sznuk, the head of the Department of the Uniform Social Insurance in the Ministry of Labour and Social Policy (orig.: Wydział Jednolitych Ubezpieczeń Społecznych w Ministerstwie Pracy i Opieki Społecznej / MPiOS) issued the main principles of the Polish act on social insurance. ${ }^{23}$ In June 1920 a draft of the act was prepared..$^{24}$ The concept was brave; its assumptions based in the idea of non-existence of any occupational groups which would be granted special rights and obligations. The system was supposed to be uniform and covered all who were employed. Everyone who was insured was offered the same rights and obligations. The whole range of risks was secured, including: sickness, incapability to work, work-related accidents, oldness, maternity, death and a lack of work. Authors anticipated exclusion of the certain groups like the state employees and other groups whose insurance was regulated based on other principles.

The concept of social insurance which was introduced in 1920 could be considered as the first attempt of implementation of the policy of caution executed by the state. It was assumed that the state would create and conduct the policy whereas the citizen was supposed to be a subject of the activity, in accordance with the principle described by Z. DaszyńskaGolińska which stated that:

Departments and Offices of the Provisional Council of State of the Kingdom of Poland executed or prepared during their existence, from January 15 to September 1, 1917], Drukarnia Państwowa Królestwa Polskiego, Warszawa 1918, p. 30-32.

22 Sekcja ubezpieczeń społecznych (Sprawozdanie za kwiecień, maj i czerwiec 1919 r.) [Social security section (Report for April, May and June 1919)], Biuletyn Ministerstwa Pracy i Opieki Społecznej, no. 3/1919, p. 75-76.

${ }^{23}$ Sznuk Tadeusz, Zadania polskiej polityki państwowej w dziedzinie ubezpieczeń społecznych [Polish state policy tasks in the field of social security], Biuletyn Ministerstwa Pracy i Opieki Społecznej, no. 3/1919, p. 172-177.

24 The State Archive in Poznan (Archiwum Państwowe w Poznaniu, APP), The Social Insurance Institution in Poznan (Zakład Ubezpieczeń Społecznych w Poznaniu), sign. 2, p. 120-151, Ustawa o ubezpieczeniu społecznem. Zarys projektu [Social Security Act. Bill outline]. 
People are not enough precautionary, even if it's about their own future, to let them act freely. ${ }^{25}$

By introducing mandatory insurance, the state fulfilled its duty. The other side of the coin was the reality of the idea, the possibility of putting it into practice, which did not seem optimistic. All in all, it was a reliable project, sort of the leading idea of the policy of caution, a part o which was supposed to be social insurance system.

The idea, however, has never came into existence, into legislative phase. Never has it been in the form of project discussed by the Council of Ministers or any state legislature. It did not mean, however, that it stopped existing. An attempt to implement the project could be seen in the activities of MPiOS in the first years of existence of the Second Republic of Poland. The authors assumed that the system of social insurance in Poland would be implemented by introduction of insurance against sickness system together with the one against accidents. The first one was supposed to be its local institutional chain of branches whereas the second one was supposed to be a system managed centrally. In May 1920 a law on insurance against sickness was adopted. Why, though, insurance acts regarding two separate risks have been introduced instead of the project of act as of June 1920? In May the same year, a law on insurance against sickness was adopted. ${ }^{26}$ It seems as if it was an attempt to execute the idea, somehow, from the back door. Moreover, Feliks Turowicz, during the parliamentary debate in May 1920, confirmed the aforementioned assumption by saying that

[...] by creating health maintenance organization, we create organizational background for another insurance. ${ }^{27}$

There was a concept of developing in Warsaw a central insurance institution, which - however - did not succeed. It was decided to strengthen the position of the Department of Insurance against Accidents in Lviv (orig.: Zakład Ubezpieczeń od Wypadków we Lwowie), which was only a temporary action and resulted from the slow pace of introduction of the insurance against sickness system as well as from a lack of political

\footnotetext{
${ }^{25}$ Daszyńska-Golińska Zofia, Ubezpieczenia społeczne... [Social security...], p. 7.

${ }^{26}$ Dziennik Ustaw Rzeczypospolitej Polskiej [Jouranl of Laws of the Republic of Poland] (DzuRP) 1920, no. 44, item 272.

27 Sprawozdania Stenograficzne z posiedzeń Sejmu Ustawodawczego [Shorthand reports from legislative Sejm sessions] (SSSU) 1920, no. 134, column 16.
} 
compromise regarding the overall concept of the Polish social insurance system. As a consequence, in 1924 an Austrian law on insurance against work-related accidents was extended on the former Russian annexation. ${ }^{28}$

That way, instead of introduction of policy outlined in 1920, solutions considered as insufficient, were implemented. In 1924 and 1925 the system of insurance against unemployment, based on the Unemployment Fund (orig.: Fundusz Bezrobocia) was funded, the system that had nothing in common with the proposal as of $1920 .^{29}$ In addition, in the former Austrian annexation, there was an attempt to save the fraternity funds which were bankrupt. However, even more crucial - as it seems - was to implement legislation regarding insurance of the white-collar employees. The concept matured at the turn of 1923 and 1924, when it was decided that there would be separate insurance system for every social and occupational groups. Introduction of a pension law for both, soldiers and employees of the public sector, constitution a form of the aforementioned concept. ${ }^{30}$ Finally, after a several years of debates, in Autumn 1926, a concept of insurance for white-collar employees, based on decentralized institutional system was formed. The law was introduced in 1927 by the decree of the president. ${ }^{31}$

It is worth to mention the fact of emerging of local insurance institutions, often existing by the enterprises. Pension funds in Lodz could be given as an example of such activity. They existed by the Power Station in Lodz (orig.: Elektrownia Łódzka), the Lodz Narrow Gauge Electric Commuter Rail (orig.: Łódzka Wąskotorowa Elektryczna Kolej Dojazdowa), the Lodz Electric Railway (orig.: Łódzka Kolej Elektryczna) and by the Municipal Gasworks in Lodz (orig.: Gazownia Miejska w Łodzi). Both, existence and development of institutions such as the ones mentioned above, extended the already existing disparities between employees of the different companies and led to privileges for the certain social and occupational groups.

During the first years of existence of the Second Republic of Poland, the concept assuming introduction of the state, mandatory and general so-

${ }^{28}$ DURP, 1924, no. 16, item 148.

${ }^{29}$ Chylak Karol, Systemy ubezpieczeń na wypadek bezrobocia w Polsce międzywojennej [Unemployment insurance systems in interwar Poland], [in:] Żarnowski Janusz [ed.], Metamorfozy Społeczne. Państwo i społeczeństwo Drugiej Rzeczypospolitej [Social Metamorphosis. State and society of the Second Polish Republic], Polska Akademia Nauk, Warszawa 2014, p. 227-229.

30 DzURP. 1924, no. 6, item 46.

${ }^{31}$ DzURP, 1927, no. 106, item 911; no. 118, item 1016. 
cial insurance, which included both, far-sightedness and foresight, foundered. Again, there came back to the regulation dedicated to the certain social and occupational groups. In principle, the aforementioned act on insurance against sickness covered all persisting from employment. It was supposed to narrow disparities which existed between different social and occupational groups. A law-speed process of implementation of the act resulted in situation that the truly insured were only citizens of the cities. Moreover, in former Austrian annexation, an execution of the act was suspended with reference to the employees of agriculture and forestry sectors. ${ }^{32}$ An amendment of the act on insurance against accidents as of 1921, which extended the insurance coverage, was revoked in 1924. In addition, an insurance obligation was limited to those employed in agriculture sector in farms over $50 \mathrm{~h} .{ }^{33}$ The deputy of the Polish Socialist Party (orig.: Polska Partia Socjalistyczna), Tadeusz Reger, said directly about a privileged position of the citizens of the Lesser Poland (orig.: Małopolska), unlike other parts of the country, and he called it "privilegium odiosum for the Lesser Poland". ${ }^{34}$ As it was mentioned, there was a separate insurance system dedicated to the white-collar employees of the private sector, miners as well as the employees of the public sector and the soldiers. There were separate ways of development of insurance against unemployment. The systems differentiated in terms of financing, contributions paid by

32 The Central Archives of Modern Records in Warsaw (Archiwum Akt Nowych w Warszawie, AAN), The Presidium of the Council of Ministers, Protocols of the Council of Ministers (Prezydium Rady Ministrów, Protokoły Rady Ministrów, PRM, Prot.RM), sign. 15, p. 46, Protokół z 81-go posiedzenia Rady Ministrów RP z 12 lipca 1921 r. [Minutes of the 81st Council of Ministers of the Republic of Poland Session of July 12, 1921]; p. 5051, Pismo MWRiOP do MPiOS z 7 maja 1921 r. [Official letter form MWRiOP to MPiOS, May 7, 1921]; p. 52-53, Pismo MPiOS do MWRiOP z 21 grudnia 1921 r. [Official letter from MPiOS to MWRiOP, December 21, 1921]; p. 54, Wniosek na Radę Ministrów o obowiązkowym ubezpieczeniu na wypadek choroby [Proposal for Council of Ministers on obligatory sickness insurance]; APP, Regional Insurance Office (Okręgowy Urząd Ubezpieczeń), sign. 11, p. 9a, Official letter from Ministry of Labour, Welfare and Health (Ministerstwo Pracy i Opieki Społecznej, MPiOS), October 10, 1924; p. 10, Official letter from MPiOS, June 27, 1922; p. 11, Official letter from MPiOS December 3, 1920; DzURP, 1922, no. 18, item 149; 1923, no. 75, item 875; 1925, no. 129, item 918; Sprawozdania Stenograficzne z posiedzeń Senatu Rzeczypospolitej Polskiej [Shorthand reports from the Republic of Poland Senate sessions] 1923, no. 26, column 4-47; 1925, no. 121, column 25.

33 Pęski Józef, Zakres ubezpieczenia od wypadków w świetle orzecznictwa Najwyższego Trybunatu Administracyjnego [Accident insurance extent in the light of the Supreme Administrative Court jurisprudence], Praca i Opieka Społeczna, no. 1/1928, p. 60-63; DzURP 1921, no. 65 , pos. $413 ; 1924$, no. 16 , item 148 ; no. 50 , item 512.

${ }^{34}$ SSSU, 1921, no. 241, column 7. 
the insured and the employers as well as the benefits the systems offered. That way, there were social groups whose risks resulting from work were fully covered, other groups which were offered only limited benefits and the groups which actually did not benefit from the insurance at all. There were ones who fully financed their benefits, other ones who participated in the costs together with the employers and finally the ones who were financed from the budgetary funds.

In 1920, when the act on insurance against sickness was proceeded, the deputy of the National Workers' Party (orig.: Narodowa Partia Robotnicza), Ludwik Waszkiewicz, pointed out that introduction of the social insurance was a part of a far-sighted policy and should cover all working people so that when they were not able to work due to any reason, they did not constitute a "burden for the public charity" ${ }^{35}$ Moreover, he emphasized the importance of a principle of equality in terms of treatment of different social groups and the necessity of the mandatory insurance. Edward Pepłowski, the minister of labour and social welfare in the government of Leopold Skulski, said proudly that such variety of groups of employees obliged to be insured meant that $70 \%$ of the society of the Second Republic of Poland was covered by the system (insured). On the contrary, the deputy of the National Democracy, Stefan Rottermund, commented with irony that "such a common insurance is unique on a world's scale". ${ }^{36}$ It is worth to mention that in that time the social insurance was treated as an instrument to attract people who voted for their nationality in Upper Silesia (orig.: Górny Śląsk), Cieszyn Silesia (orig.: Śląsk Cieszyński), Warmia (orig.: Warmia) and Masuria (orig.: Mazury) as well as to distance the partitioning countries and to protect the country from the influences which came from the eastern border ${ }^{37}$ In such reality it was difficult to talk about any long-term policy of caution.

At the end of the 20s of the 19th activities regarding reform of the whole insurance system were intensified. They aimed at organizational uniformity as well as equality of the certain social and occupational groups. After several years of discussions, at the beginning of 1929, the Council of Ministers approved the project of the act. ${ }^{38}$ It was sent to the Sejm and soon

35 SSSU, 1920, no. 129, column 47.

36 SSSU, 1920, no. 133, column 9.

37 SSSU, 1920, no. 129, column 45.

38 Druki Sejmu RP 1929 [The Republic of Poland Sejm Works, 1929], no. 487; AAN, PRM, Prot. RM, sign. 46, p. 132 Protokół z posiedzenia Rady Ministrów RP z dnia 20 marca 1929 r. [Minutes of the Council of Ministers of the Republic of Poland Session of February 
withdrawn. That way, the next step of conceptual works started. After two consecutive years, in March 1932, the Council of Ministers approved the new project, which was fundamentally changed during the parliamentary works and in March 1933 it was finally enacted. ${ }^{39}$ One year later the system was reorganized. ${ }^{40}$

The new act on social insurance resulted in liquidation of many distortions in the statuses of different social and occupational groups in that regard. It covered insurance against sickness, accidents and pension insurance. The insurance was supposed to cover all persons, with no regard as to the sex and age, who were employed or on their duty. In addition, the remaining part of the society was entitled to insurance as well, however in that case it was optional and voluntary. The general principle was, however, the employment status (an obligation to be employed). That way, within the insurance system, the differences of the statuses between the particular social and occupational groups were liquidated. It constituted an attempt to execute citizens' rights, which were defined in the constitution dated 1921 (art. 102), which made the state to protect its citizens. The basic needs of every employed, in case of incapability to work due to fortuitous events, were covered by the insurance. The state's attitude was thereby forward-looking and preventive; it must be said that the state executed the policy of foresight. The citizens were it's active participants by sharing costs of that insurance.

Nonetheless, a more thorough analysis of the act could lead to a conclusion that equality of the certain social and occupational groups was only a delusion. There was a number of exceptions from the aforementioned principle. First of all, the regulator excluded the employees of the public sector, who were covered by the legislation as of December 1923, as well as railway men, soldiers, clergymen, etc. ${ }^{41}$ That way, the aforementioned group of people had better position than the group remained in the system of social insurance. Even more important, basically because of the number of people involved, was exclusion of the employees of the agricultural and forestry sectors from the insurance against sickness as well as the pension insurance. Even though, both groups of people were secured as the employers of both sectors mentioned above were obliged to finance

20, 1929]; Z Rady Ubezpieczeń Społecznych [From the Social Security Council], Praca i Opieka Społeczna, no. 2/1927, p. 75-77.

${ }^{39}$ DzURP, 1933, no. 51, item 396.

40 DzURP, 1934, no. 95, item 855.

${ }^{41}$ DzURP, 1923, no. 26, item 239; 1932, no. 61, item 577. 
health benefits. ${ }^{42}$ That meant that all people employed in agricultural sector were - in practice - excluded from the social insurance system (except of the insurance against accidents). Here it should be noted that in accordance with the census which took place in 1931, 60\% of all citizens of the Second Republic of Poland worked in the agricultural sector and 2.85 million of them were employed. It constituted nearly third part of all people who were employed. ${ }^{43}$

The act on social insurances, although it promoted a principle of equality, liquidated some and created other divisions. The assumptions regarding occupational divisions vanished whereas more and more popular became class thinking. The aforementioned law was a vivid emanation of such assumptions. The environments of the white-collar workers, as well as the ones employed by the state, became privileged. Moreover, additional rights were given to people employed elsewhere except the agricultural sector whereas all employed in agricultural and forestry sectors were denied the rights. It is worth to mention, however, that $60 \%$ of the citizens who were outside the system, did not oppose. Moreover, they did not demand to be included into the insurance system. And even more, since the very beginning, in the parliament, the peasant parties strived for exclusion of that occupational group from the system. ${ }^{44}$ Therefore, there comes the question if the insurance system in its form was in fact a privilege. Perhaps a lack of reaction from the agrarian sector resulted from its organizational status as well as a level of education. Or, perhaps, the villagers executed their own policy of caution by traditional family, by fostering multigenerational links, by commitments between parents and their children.

The policy of the Polish authorities, in regards to the social insurance, was not consequent, which was particularly visible in the 20s. It seemed,

42 DzURP, 1933, no. 87, item 673.

43 Szturm de Sztrem Edward, Drugi powszechny spis ludności z dn. 9.XII.1931 r. [Second Polish Census of December 9, 1931], Polska, Główny Urząd Statystyczny, Warszawa 1938, tabl. 18.

44 APP, The Ministry of the Former Prussian District (Ministerstwo byłej Dzielnicy Pruskiej). sign. 791, p. 97-98, Protokół z drugiego zjazdu Komisarzy Kas Chorych dnia 12 maja 1921 roku [Minutes of the Second Convention of Health Maintenance Organization Commissioners of May 12, 1921]; Sprawozdanie Zakładu Ubezpieczeń od Wypadków we Lwowie [Accident Insurance Office in Lviv Report], Zaklad Ubezpieczeń od Wypadków, Lwów 1926, p. 3; Sprawozdanie z działalności Ministerstwa Pracy i Opieki Społecznej w r. 1921 [Department of Labor and Social Security Activity Report for 1921], Praca i Opieka Społeczna, no. 2/1922, p. 119-1920; Sprawozdanie z działalności Ministerstwa Pracy i Opieki Społecznej w r. 1922 [Department of Labor and Social Security Activity Report for 1921]; Ibidem, no. 2/1923, p. 111. 
however, that after implementation of the uniform act on social insurance, the state's policy would become more changeless. The situation in the Upper Silesia (orig.: Górny Śląsk) was justified, however, because of the obligations resulted from the peace treaty and the Geneva Convention as of 1922, the possibilities of introduction of the reforms were considerably limited. The rights acquired by the people employed were protected. The rest of the country was free from such limitations. Meanwhile, when the legislation on the social insurance - considered as the final regulation in regards to consolidation of the system - was enacted, there came postulates of development of the institutional network by the Social Insurance Institution (orig.: Zakład Ubezpieczeń Społecznych). One of them was a proposal of founding of the institution responsible for insurance against sickness for the agricultural sector ${ }^{45}$ In 1934 the State Pension Institution (orig.: Państwowy Zakład Emerytalny) was established. It was designed to service the state's employees. ${ }^{46}$

A particularly vivid example was a policy towards the mine industry insurance. Shortly after the act on social insurances came into force, there came the decision on liquidation of the fraternity funds w Galicia. The Miners' Fraternity Association (orig.: Bractwo Górnicze) in Cracow was put in the state of liquidation in 1933, as well as the Fraternity Fund "Silesia” in Czechowice and the Fraternity Fund in Boryslav. The office of the Cracow institution was transformed into the temporary branch of the Workers' Insurance Pension Institution (orig.: Zakładu Ubezpieczenie Emerytalnego Robotników). ${ }^{47}$ Only the post-German mine industry insurance system in the Upper Silesia remained unchanged. It operated as an additional insurance. ${ }^{48}$ In 1933 the miners from the former Russian annexation were included in the general insurance system. It did not mean, however, that their former insurance institutions' activity would be terminated, which resulted in different status of the miners, who worked in the not so remote cities like Chrzanów, Katowice and Sosnowiec. In 1935, there came a decision to reform insurance institutions from Dąbrowa Basin

45 Duch Kazimierz, Ubezpieczenia społeczne [Social security], Spółka Wydawnicza „Libris", Warszawa 1934, p. 331-333.

46 DzURP, 1933, no. 86, item 668.

47 Sprawozdanie Zakładu Ubezpieczenia Emerytalnego Robotników za rok 1934 [Workers' Pension Insurance Office Report for 1934], Zakład Ubezpieczeń Społecznych, Warszawa 1937, p. 71, 76.

48 DzURP, 1933, no. 51, item 396; Wanatowicz Maria, Pszczyńskie bractwo... [Miners' Guild in Pszczyna ...], p. 31-38. 
(orig.: Zagłębie Dąbrowskie). ${ }^{49}$ It resulted in establishing of the Fraternity Fund of the Dąbrowa Basin with its location in Sosnowiec. That insurance was, similarly to the one in the Upper Silesia, additional. In 1938 the authorities decided that the activity of that insurance institution would be extended on the following districts: Bielsko and Chrzanow. At the same time, the retirement age, determined as 60 years, was introduced..$^{50}$ That way, the reform dated 1933 was revoked. The miners received additional insurance. In that certain case it could be said that they were given a privileged status, particularly because the finances of that system were additionally supported from the state budget.

\section{CONCLUSIONS}

The process of creation of the social insurance system in Poland did not - as it seems - represent the policy of caution executed by the state. The only sign of caution could be seen with reference to the insurance associations as there the participants decided whether to enter the system or not. The participants, who - in fact - were willing to insure themselves and voluntarily paid certain contributions and - consecutively - were given possibility to benefit from the certain privileges. The state, on the other hand, executed the policy of giving privileges to the certain social groups. The motives of such policy varied one from another. Sometimes it was a willing to gain support, some other time it was a policy of defense of someone's' influences, finally, a willing to spike arguments of the opposition. Such motives could be listed endlessly. Social equality as well as social rights were, in practice, only representing a substitution of one differences by the others. It, in addition, reflected deprivation of privileges for some groups and, simultaneously, granting them to the others.

Karol Chylak - PhD, Assistant Professor at University of Social Sciences in Lodz. Scientific interests: social and economic history. Author, co-author and editor of several books. Recently published: The multi-religious city of Lodz. History of religious communities before 1914, Lodz 2015.

49 DzURP, 1935, no. 65, item 410; Fischlowitz Stanisław, Reforma ubezpieczenia górników w Zagłębiu Dąbrowskim [Miners' insurance reform in Dąbrowa Basin], Przegląd Ubezpieczeń Społecznych, no. 10/1935, p. 639-640.

50 DzURP, 1938, no. 69, item 505; M[amrotowa] Wanda, Sprawa kas bratnich w Zagłębiu Dąbrowskiem, Przegląd Ubezpieczeń Społecznych no. 7/1935, no. 7, p. 712. 